When, some time ago, I consulted two imaginary charts, by Mr. Jukes-Browne, of Pleistocene times, ${ }^{1}$ I found that in neither did the sea approach the Torbay raised beaches! A sea-beach without a sea is impossible.

Mr. Lamplugh, in the current number of the Geological Magazine, seems to have exactly defined the present position of this raised beach question. He observes that "the correlation has still an element of uncertainty" ${ }^{2}$ That is all I at present maintain, viz., that the age of these Torbay beaches has not been "fairly well settled".

If Mr. Jukes-Browne can justify his charge, by reference to any passage of mine in the Geological Magazine (since 1890); that I am a "needless fault-finder", I will give $£ 5$ to any hospital or to any scientific object that you, Sir, may kindly indicate.

SOUTHWOOD, TORQUAY.

A. R. Hunt.

May 3, 1913.

\title{
THE 'CRETACEO-TERTIARY' OF NEW ZEALAND.
}

Sir,-I noticed that in the November number of the Geological Magazine there was a further criticism of my work on the rounger rock system of New Zealand. At this distance it is, I think, inadvisable to detail at great length the exact features of local stratigraphy. This I intend to do in the pages of the Transactions of the New Zealand Institute, the publication in which my first article on this subject appeared. I hope, however, that you will find space for a reply on a few of the more general aspects of the question.

1. Insistence is laid on the fact that below the Oamaru Limestone Cainozoic fossils only have been found, while beneath the Amuri Limestone Cretaceous fossils occur. As a matter of fact, in all those districts where the Amuri Limestone has been found there is a thickness of 500 to 2,000 feet of strata that have up to the present time yielded no fossils, while the Amuri Limestone itself is almost destitute of fossils, though those that have been found are of Tertiary aspect.

The explanation that I have put forward, viz. continuous rapid depression until after the deposition of the limestone, makes it evident that in off-shore and in relatively low-lying localities the deposition of limestone would commence far earlier than in localities that were submerged only slightly before the climax of depression. 'The thick deposits of foraminiferous ooze which is the nature of the Amuri Limestone must, therefore, represent not merely in its upper part the same horizon as the Oamaru Limestone, but in its lower part a considerable thickness of subjacent beds, be they conglomerates, greensands, or mudstones. One may add, too, that the latest critical statement (1892) of Tate classes the Echinoderms of the Oamaru Limestone (twenty-six species, all extinct) as Eocene with a Cretaceous complexion.

3 The Building of the British Isles, 1888, pp. 294, 300 .

${ }^{2}$ GEOL. MAG., 1913, p. 239. 
2. 'The sections 500 miles away in the north of Auckland are again quoted as explanatory of the supposedly misleading nature of the well-known clear section at the Waipara. I have just returned from a visit to these localities, and find that the sections represent inferences only, for in the one case (Kaipara) the section is obliterated by completely slipped ground for a distance of six chains, and in the other (Orewa) for ten chains. In both cases the stratigraphical break in the diagram is placed where the slipped ground is situated. At the Kaipara the original description distinguishes the strata as Jurassic and Upper Tertiary respectively. At Orewa the strata on the two sides of the slipped ground are not fossiliferous, and in the original description neither of them was assigned to any particular geological age.

3. Hutton's stratigraphical break between the two limestones is in Professor Park's article adopted as the plane that separates the Cretaceous from the Tertiary rocks. In 1904 the same author, in a critical description of this district traversing Hutton's work, states in his conclusion (ii) "That the Weka Pass Stone is conformable to the Amuri Limestone". And in his résumé (m) "The Weka Pass Stone is always conformable to the Amuri Limestone". He now states that previous to 1912 he had not critically examined the surface of the Amuri Limestone. Surely it is remarkable to make the statements quoted above entirely contradictory of Hutton's work without critically examining the surface upon the nature of which Hutton relied, though it must have been seen. One of his sections in the paper referred to actually represents his view of Hutton's typical exposure. An author who works thus can hardly be taken seriously.

4. May I add a word of personal explanation. Twenty years ago I graduated from the instruction of my revered teacher, the late Captain Hutton, F.R.S. Impressed by his wide erudition and by his capacity for work, I naturally accepted without question his views on New Zealand stratigraphy. To these I clung for many years, and tried to apply them to those districts where I was at work. Difficulties, however, multiplied and in time became insuperable. I finally went to Hutton's typical localities in the confident expectation that information gained there would solve my difficulties. Surprise and regret were great when I found that, in my opinion, the stratigraphical facts had been represented erroneously by $\mathrm{my}$ old teacher. The so-called Cretaceo-Tertiary theory never had any attraction for me. Hard facts in field work have compelled me to accept a series of sediments continuously deposited, rising from beds with Cretaceous fossils to others with younger Cainozoic fossils. This was in opposition to my fondest expectations.

P. Marshatl, Professor of Geology, Otago University, N.Z.

UNIVERSTTY OF OTAGO, DUNEDIN, N.Z. April 4, 1913. 